ROCZNIKI TEOLOGICZNE

Tom LXVI, zeszyt 7 - 2019

DOI: https://dx.doi.org/10.18290/rt.2019.66.7-3

REV. MARGRIET GOSKER

\title{
SO WHAT? \\ SOME EXPERIENCES OF SECULARISM \\ IN THE NETHERLANDS AND MY OWN WAY TO HANDLE IT AS A LOCAL PASTOR*
}

\begin{abstract}
A b s tract. The article consists of three parts. In the introduction, it is stated that there are a lot of different ideas and theories about secularism, and some short highlights are given, positively as well as negatively. In Poland, secularism is different from secularism in the Netherlands, one of the most secularized countries in Western Europe. In the second part, the author shows how, as a local pastor, she experienced secularism during the last five decades: indifference, loss of commitment and biblical knowledge, also concerns about office bearers, closing of churches, the loss of feeling for the sacramental life of the church, closing of several theological faculties, etc. On the other hand, the positive side of secularism is not only about more authenticity and elasticity in the Church (less obligatory duties), but also the abolition of slavery, more freedom for women and children and more freedom for minorities. In the third part, the author shows how we take up new challenges, including new forms of episkopè, pioneer places and the music event of the Passion. She closes with some open questions waiting for answers. The answers are very important for the ecumenical movement as a whole.
\end{abstract}

Key words: ecumenism; secularism; "end of Christianity"; faith; commitment; Ordination; Episkopè; the Passion; pioneer places; the Netherlands.

\section{INTRODUCTORY REMARKS}

There are a lot of different ideas and theories on secularism ${ }^{1}$ and sometimes they are contradictory. ${ }^{2}$ Is secularism different from secularisation?

Rev. Dr. MARgriet GoSKer - an ecumenical theologian, reverend emeritus of the PCN. She worked for the Community of Protestant Churches in Europe (CPCE), for the World Council of Churches (WCC), and for the World Communion of Reformed Churches (WCRC), member of Societas Oecumenica; address for correspondence-e-mail: dr.m.gosker.venlo@hetnet.nl.

${ }^{*}$ Rev. Harvey Richardson, Methodist minister in Britain, corrected my English. I thank him for his kind help.

${ }^{1}$ The term 'secularism' was first used by George Jacob Holyoake. He invented the term to describe his view of a social order apart from religion, without actively criticizing religion. "Secu- 
Not only the English, but also the German language distinguishes between Säkularisierung, Säkularismus and Säkularisation, ${ }^{3}$ but in our Dutch language these nuances are not so clearly recognised. ${ }^{4}$ Is secularism absence of God, and how should we deal with agnostic contemporaries ${ }^{5}$ ? Is it a kind of atheism, or a movement against Christianity, questioning its pretensions? Is it indifference to religion, or even a rejection of it? Does secularism mean that churches lose power and influence more and more, and will they eventually vanish completely? Is it a clash of values? $?^{6}$ Is it awful like acid rain or is it—on the contrary—a blessing? ${ }^{7}$ Or is it simply nothing to worry about? ${ }^{8}$ Is secularism a helpful principle of strong separation between church and state? Is it an ideology, threatening religious freedom? Or is it just fine, shifting the focus from religious ideas to modern life with a big emphasis on science, nature and enlightenment? Why do some people even speak of the 'neurosis' of secularism?'

All those questions arise, but it is not the aim of this article to discuss all different theories of secularism. I leave that to the experts. As I was asked to deliver a contribution on secularism in the Netherlands, I hesitated. Most of the quoted literature is not in English of course, and why would secularisation in the Netherlands be interesting for Polish readers? Is our situation a forerunner of what could also happen in Poland? The Polish Archbishop Jeremiasz, President of the Polish Council of Churches in 2012, said at

larism is that which seeks the development of the physical, moral, and intellectual nature of man to the highest possible point, as the immediate duty of life - which inculcates the practical sufficiency of natural morality apart from Atheism, Theism or the Bible — which selects as its methods of procedure the promotion of human improvement by material means, and proposes these positive agreements as the common bond of union, to all who would regulate life by reason and ennoble it by service." George Jacob HolyOAKE, "Principles of Secularism," 17, Project Gutenberg, accessed 03.01.2019, https://www.gutenberg.org/files/36797/36797-h/36797-h.htm.

${ }^{2}$ Staf Hellemans, Het tijdperk van de wereldreligies. Religie in agrarische civilisaties en in moderne samenlevingen (Zoetermeer: Meinema, 2007), 18.

${ }^{3}$ L.J. RogIER, "Rede gehouden voor het Congres van de Organisatie van Reünisten der Societas Studiosorum Reformatorum te Lunteren op 29 september 1967," in George PUCHINGER, Christen en Secularisatie (Delft: Meinema, 1968), 9.

${ }^{4}$ Guus Meuleman, "Het begrip secularisatie," in Gerard DekKer, K. Ulrich GäBler, Secularisatie in theologisch perspectief (Kampen: Kok, [1988]), 16.

${ }^{5}$ Wim DeKKer, Afwezigheid van God. Een onderzoek naar antwoorden bij W. Pannenberg, K.H. Miskotte en A. Houtepen (Zoetermeer: Boekencentrum, 2011), 265.

${ }^{6}$ Domenico Melidoro, Principles of Secularism. Is the Clash among Principles Necessary? ResearchGate, accessed 03.01.2019, https://www.researchgate.net/publication/264120006_The _Principles_of_Secularism_Is_the_Clash_among_Values_Necessary.

${ }^{7}$ Dick TiELEMAN, Sekularisatie - zure regen of zegen voor geloof en kerk? (Kampen: Kok, 1989).

${ }^{8}$ Paul B. CLiTEUR, “Op zoek naar het bezielend verband.” Justitiële verkenningen 20 (1994), 6: 13.

${ }^{9}$ Van Oyen, in George Puchinger, Christen en Secularisatie (Delft: Meinema, 1968), 192. 
a gathering of the Conference of European Churches in Warsaw on 5 April, that in his view secularism is urgently needed to correct the way churches are using their power. ${ }^{10}$ I think in the Netherlands this process is already complete. On the contrary: our National Council of Churches organised a symposium on secularism in 2016, at which the Roman Catholic professor Erik Borgman vehemently refused to accept the new intolerance of our liberal elites who are trying to impose their liberal ideas on the whole of society. ${ }^{11}$

In the following I will not give a detailed overview of secularism in my country. I just want to show how, as a local pastor, I tried to handle it during my ministry of nearly five decades in several parishes ${ }^{12}$ of what is now the Protestant Church in the Netherlands, instituted in $2004 .{ }^{13}$ Finally I show some important developments in general on a national level and some interesting new initiatives.

\section{5-1972: SECULARISM AND THE ‘GOD IS DEAD’ THEOLOGY}

As a child I was a pious girl and I felt 'the call' to be a minister. When I started my studies in theology in 1965, it was a time of big theological changes. During the period I was a student, the priestly ministry was opened up for women, so I was ordained directly after I had finished my theological education. In that period a lot of books appeared on secularism and the socalled 'end of the Christian era'. ${ }^{14}$ I was confronted with the 'God is dead' theology. The idea that God is dead, once initiated by thinkers such as Heine, Hegel and Nietzsche, ${ }^{15}$ now became very popular. Many books ap-

\footnotetext{
${ }^{10}$ Raad van Kerken in Nederland, accessed 31.01.12019, https://www.raadvankerken.nl/pagina/ 1670/secularisatie_door_een_poolse_mi\&highlight=secularisatie (accessed 31.01.2019I.

${ }^{11}$ Raad van Kerken in Nederland, accessed 31.01.12019, https://www.raadvankerken.nl/pagina/ 4140/intolerantie_van_establishment\&highlight=borgman.

${ }^{12}$ In the beginning of my career I served the RCN (Reformed Churches in the Netherlands). This is the church wherein I was baptised in. The RCN was involved in a reunification process with the NRC (Netherlands Reformed Church) and (a bit later) the ELC (Evangelical Lutheran Church in the Kingdom of the Netherlands). Then - after the federation-I served the Together on the way Churches and finally the Protestant Church in the Netherlands (PCN).

${ }^{13}$ Arjan Plaisier and Leo J. Koffeman (eds.), The Protestant Church in the Netherlands: Church Unity in the $21^{\text {st }}$ Century (Wien, Zürich, Berlin: LIT Verlag, 2014).

${ }^{14}$ Jan JonKers and Jan te Winkel, Adieu. Mensen keren de kerk de rug toe (Leeuwarden: Jongbloed, [1980]; Rudolf Boon, Het Christendom op de tocht. Een onderzoek naar de opkomst van het West-Europese atheisme (Kampen: Kok, 1976).

${ }^{15}$ Friedrich NieTzSCHE, Die fröhliche Wissenschaft (Chemnitz: Verlag von Ernst Schmelzner 1882), § 125; Norbert SCHIFFers, “Analyses bij Nietzsches 'God is dood'," Concilium 17 (1981), 5: 72-84; A.A.A. Prosman, Geloven na Nietzsche (Zoetermeer: Boekencentrum, 2007).
} 
peared about the very existence of God, ${ }^{16}$ the dying God, the death of God, God after the death of God, the grave of God etc., ${ }^{17}$ and there were also many 'still' titles, telling us that there are 'still' believers and 'still' churchgoers. A famous question was: "Are your children still going to church?" For me as a student it was a bit confusing, but also exciting. Was my faith, our faith, strong enough to overcome my doubts? In fact I was not really doubting or struggling at the time, but I was curious enough, and I wanted to know how it was possible that people could live without being salvaged in God's care?

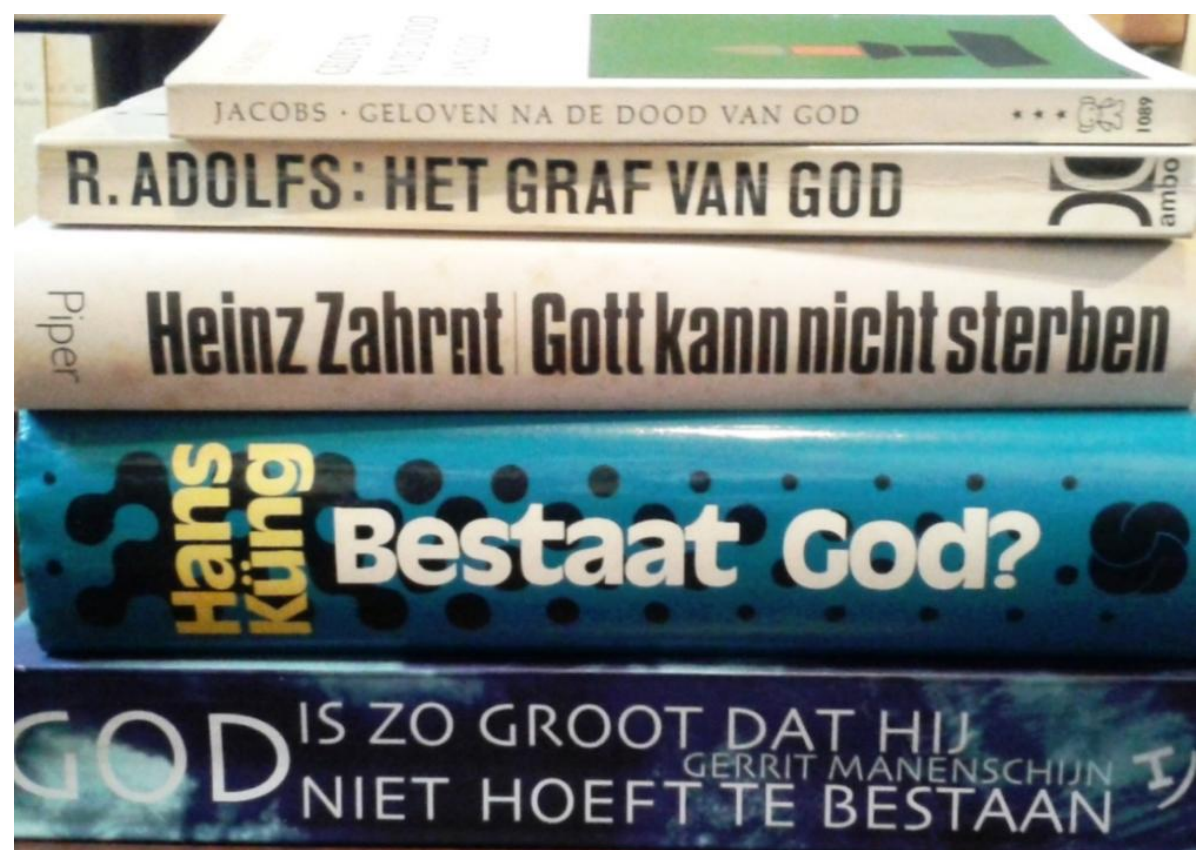

Translations of titles: God is so great: He does not need to exist. Does God exist? God cannot die. God is dead. The grave of God. Faith after God's death.

\footnotetext{
${ }^{16}$ Hans KÜNG, Bestaat God? Antwoord op de vraag naar God in deze tijd (Hilversum: Gooi en Sticht, 1978). Original German edition: Existiert Gott? Antwort auf die Gottesfrage der Neuzeit (München, Zürich: R. Piper \& Co. Verlag, 1978).

${ }^{17}$ Heinz ZAHRNT, Gott kann nicht sterben (München: R. Piper \& Co. Verlag, 1970); Janet van DIJK (ed.), God is niet dood, Toer van de Protestantse Kerk in Nederland (Zoetermeer: Boekencentrum, 2007); Robert AdolfS, Het graf van God (Utrecht: Ambo, 1966); J.G. JACOBS, Geloven na de dood van God, Reeks Witte Beertjes 1089 (Utrecht, Antwerpen: A.W. Bruna \& Zoon, 1967; Gerrit MANENSCHIJn, God is zo groot dat Hij niet hoeft te bestaan (Baarn: Ten Have, $2002^{2}$ ).
} 


\section{2-1978: SO WHAT?}

I became a pastor in a village, 32 miles away from Amsterdam. It was 1972. The village was both a rural and a dormitory community. We had three church buildings at the time. Two of them are now closed. Quite a few peasants were church members, and they were-as elders and deaconsalso part of the church governing body. Good people, with a high level of responsibility and biblical knowledge. They read the Bible daily, but they also read the church magazines, and they were well informed about church, state and society. Another part of this parish was the growing number of commuters, sleeping in the village, but working in Amsterdam. They were also greatly involved in church life at all levels. I cannot say there were conflicts between the established members and the newcomers. But if there were, we could handle it. In the six years I was there, the parish was young and it grew very quickly. The old church building was still in charge, and a new church building had been put into use. There were many children, and

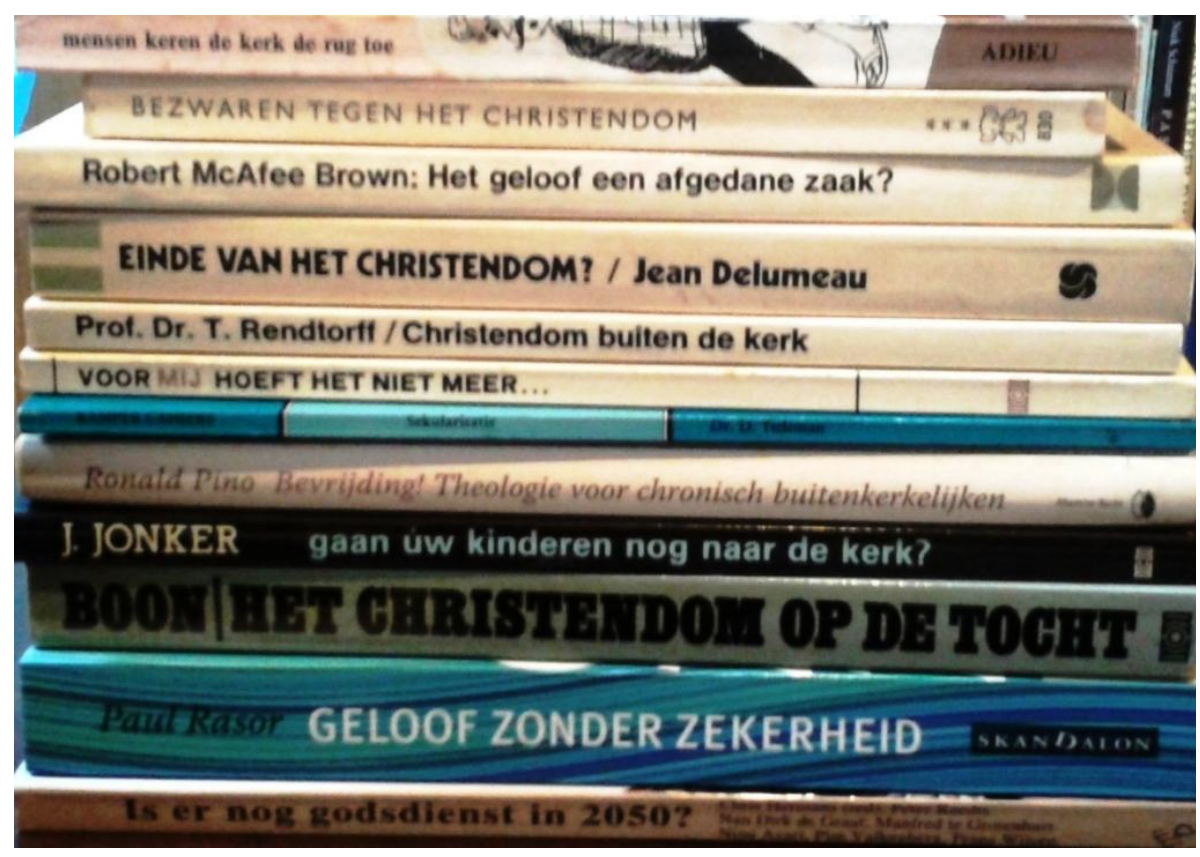

Translations of titles: People say goodbye to church. Drawback against Christianity. Faith is over? End of Christianity? Christianity outside the church. No more needed. Theology for chronic outsiders. Are your children still going to church? Christianity at risk. Faith without being certain. Is there still any religion in 2050 ? 
we had a large number of baptisms, marriages and confessions. I often preached three times each Sunday. But I did not count my blessings. I thought it was all as usual and normal. Secularism? Yes, I heard about it and I read about it, but I did not see it around. But there were some small indications already. I remember one of the members wanted to strike his name off the membership list. I visited him and we had a conversation. Most of it I have forgotten, but I shall never forget his answer, when I said: "Why should you do this? If there are more people doing the same, we will have no church any more in the end." I was really shocked by his answer. He simply said: "So what?" For me as a young pastor it was my first impressive experience of the nature and impact of secularism.

\section{8-1985: PARSONAGE TALKS}

After moving over to my second parish appointment in 1978, I found myself in a smaller village, but less rural and just eight miles from Amsterdam. Here we enthusiastically joined in the local 'Together on the Way' process (an ecumenical process of church unification on a national level), and after a few years of hard work, we succeeded in establishing a solid church federation. We left our little white church building (Reformed Churches in the Netherlands: RCN) and went over to the greater church (Netherlands Reformed Church: NRC). The work was more difficult and a bit more stressful. People were involved and committed, we had Bible studies and a good choir, but the old differences between the two unifying communities sometimes came to the surface. For me as a pastor, it was hard to see that some elders and several members of the church council merely showed up in the service, as if they were on duty. Otherwise they simply did not go to church. This was relatively new for me. In my former parish this had not yet become the case. The members of the church council there were always people I could rely on. They were a great support for me, even in their criticisms. I could count on them at all times. They were my pillars, so to say. Whenever their term of office ended, I never forgot to thank them for their work and dedication. But one of them criticized me, by saying: "Do not think I did it for you." I was silent for a moment and then I got it. Yes, 'my' elders and deacons are not helping me, but they follow God's calling to build up God's own church and they know it. But now, in my second parish the situation seemed to have changed. My (I mean God's) elders and deacons 
were missing in the services, except for those times when they were on duty. Was this the influence of secularism? After each service on Sunday my husband and I were telling each other: "Well, did you see Bob? He was not there, and neither was Tony, and I missed Alice and Grace. And where was Tim?" It was certainly depressing. I felt as if they were letting me down. And there was also the danger that it was making me into a pastor without inspiration. I realised I was developing an element of scepticism in my attitude. I knew for sure: this must not go on like this. One Sunday, after the service I said to my husband: "From now on we will not speak with sadness about the people not present, but we shall tell each other with joy about everybody who was present!" So I decided to change completely my thinking and my way of life. Yes, it was something like a conversion. I developed a new attitude by always being glad and grateful for all the good gifts and blessings God has given me. And there are so many of them.

\section{5-2000: OPEN FOR NEW CHALLENGES}

In 1985 we moved to my third parish. It was adjacent to our capital city Amsterdam with its universities, its airport, its businesses, and all the museums. The new parish had a new church building, recently instituted with enthusiasm by members of our two Reformed wings, who were 'Together on the Way' with financial help from a foundation that supported the establishment of new churches. ${ }^{18}$ The fact that such a foundation nowadays is no longer needed is another sign of secularism. My colleague and I both belonged to different theological 'wings' of the Church. It was quite a new situation. It was a vivid community, and we had beautiful ecumenical relationships. But I noticed that it was no longer usual for many families to read the Bible in their homes. Even the office bearers had less biblical knowledge than they had in earlier times. We organised many things together, in an ecumenical way: services, and especially Bible Study groups. I noticed - as did my Roman Catholic colleague - how people were living in a society more and more secularised. But we knew that secularism also had positive aspects. It is certainly true that it was mostly secularised politicians who had worked in the past for the abolition of slavery, for the rights of unskilled workers, for the rights of women and children, and it was they who

\footnotetext{
${ }^{18}$ Henk C. EndediJK, Aan deze plaats doet Gij Uw woorden horen. De Geschiedenis van de Stichting Steun Kerkbouw, 1954-1994 (Leusden: Stichting Steun Kerkbouw, 1994).
} 
opposed discrimination of minorities. ${ }^{19}$ So we tried to be open to all new challenges. It was time to realise that we were living in changing times, where the Christian faith had a different position in a changing secular, plural culture. ${ }^{20}$ In churchly life it was more difficult to find elders and deacons or other volunteers. If I wanted to meet the youngsters, it was not normal any more that they showed up, as in earlier times. I decided, I should call them and invite them personally, and in a friendly manner. That was largely very effective. We were in the neighbourhood of the Free University of Amsterdam. I also started working with some university students, and enjoyed that very much. One day I noticed that they did not have a place where they could meet together, to discuss things and strengthen their faith. So once a month I invited them into our home; I cooked a meal for them and we could discuss everything they wanted. I did not tell them when to arrive or when to go. They could 'turn up' at any time and they could go whenever they wanted. I always had a proposal or a theme for them, and yet mostly we did not follow it. We always discussed other things, relevant to them, from a Christian point of view, such as 'how to read the Bible', 'secularism', 'individualism' and 'privatization'. In a way I became their spiritual leader. And 40 years later I still am. We never lost contact and we still meet every year.

\section{0-2004: SHRINKAGE CAUSES CRAMP}

Not only were youngsters being secularised, but also our church and many other churches were losing members; many church buildings had to be closed. What were the consequences of these developments for the social cohesion of our society? ${ }^{21}$ As I started in this suburb under the smoke of Amsterdam, we were the owners of ten church buildings. Six of them are now closed, unfortunately. This process was difficult, and it caused a lot of struggle. It was also dangerous for good relationships. Shrinkage causes cramp. Colleagues become rivals and a breeding ground for animosity grows easily. This certainly happened in the place where I served. I am a publisher, so I published many articles at the time, and I became chief editor of

\footnotetext{
${ }^{19}$ Klaas van der KAMP and Beppie VAN LAAR Raven. Over eenheid als waardering voor God (Amersfoort: Raad van Kerken in Nederland, 2014), 74.

${ }^{20}$ Henk M. VRoOM, Plaatsbepaling. Christelijk geloof in een seculiere en plurale cultuur, (Zoetermeer: Meinema, 2006), 13.

${ }^{21}$ Joep de Hart and Pepijn van Houwelingen, Christenen in Nederland. Kerkelijke deelname en christelijke gelovigheid (Den Haag: Sociaal en Cultureel Planbureau, 2018).
} 
Centraal Weekblad (a weekly national church magazine). I wrote articles in it, and many columns. Secularism was still prevalent. If somebody was called to a ministry in the church, he or she did not feel this was God's calling any more. For them it was just a voluntary job, like being a football coach in your own free time. In one of my columns I published my observation that members of church councils unfortunately did not have the same dedication and biblical knowledge as in earlier times. This was a good observation, but it would have been better left unsaid. Some people thought I meant them, which was honestly not true, but it caused me a problem and it showed how secularism affects us all deeply, not only theologically but also psychologically. It causes rivalry and struggle. I suddenly realised that I was preaching every Sunday for people who were still sitting there, but at the same time they were probably the ones abandoning the church after a while-at least many of them. And I could not prevent it. What were we doing wrong? What was I doing wrong? And what could we do? What could I do? I could just give my best, no more. And I could pray, hoping the Holy Spirit would take care of it.

\section{SECULARISM IN OUR OWN HEARTS}

As an ecumenical theologian I had the privilege of being invited in 1993 to the $5^{\text {th }}$ World Conference of Faith and Order in Santiago de Compostela. ${ }^{22}$ Many participants were there from the global South. They showed their spirituality in many ways I was not accustomed to. It was there that I realised for the first time, how secularism was rooted deeply within me, in my own heart and soul. Secularism was not only out there, it was also inside me. I had to deal with it. Back home I wanted to share my inspiring ecumenical experiences with my parish. I wanted to show them how we could share our Christian faith in ways other than our familiar ones. As an example, I hired an African choir as guest singers in our church and they brought a lot of spirituality indeed. It was really nice, but it did not work. Secularism is very strong in our society; it influences our church members, our church councils, our theologians, our ministers, elders and deacons, including myself. But I strongly believe this does not have to be. I strongly believe Christ will not leave his church alone. Secularism is a struggle in us, but it is not a lost one. ${ }^{23}$

\footnotetext{
${ }^{22}$ Thomas F. BEST and Günther Gassmann, On the way to fuller Koinonia, Faith and Order Paper 166 (Geneva: WCC Publications, 1994).

${ }^{23}$ Herman PAUL, De slag om het hart. Over secularisatie van verlangen (Utrecht: Boeken-
} 


\section{4-2010: MOVED TO THE SOUTH}

In 2004 I followed God's call to the South of our country, on another side of the main Dutch rivers. It was a big change. Until now I had been a minister in mainly Protestant areas, but now I landed in regions predominantly Roman-Catholic. All inner Protestant differences seemed to be unimportant now. However, in the place where we landed, there was still an unpleasant heritage of struggle about the closure of one of the two Protestant churches. This is frequently happening in the Netherlands, but now I could feel the damage. I was looking for ecumenical relationships as ever. Ecumenism flourished at the local level, but contacts with the Roman Catholic diocese and bishops were hard to come by. Here waited a new task for me. We contacted the Roman Catholic diocese and we build up a good ecumenical companionship. We could also build up friendships with the Roman Catholic bishops. We organised ecumenical conversations, meetings and services, including a festive 'Thomas Celebration' in 2008 especially for doubting and seeking souls. ${ }^{24}$ We discovered that all churches are confronted by the same problems. It is undeniable that many churches lose members, close church buildings and there is a shortage of volunteers, spiritual power and money. Everybody is aware of that. Looking back, I realise that only four of the ten churches I have worked in still exist. The other six are broken down or have another use. One of them is still a house of prayer, because it is now functioning as a Synagogue. On the other hand, I realise that smaller churches have more elasticity, sometimes more power and more authenticity, and they are definitely more open to new initiatives. Progression of secularism also means that members, who have decided not to abandon the church, are more committed and dedicated to Christian life.

centrum, 2017). Paul has a special chair in secularization studies at the Faculty of Theology and Religious Studies at the University of Groningen.

${ }^{24}$ The 'Thomas Celebration' was a special Service with bishop Franz Wiertz and René van der Linden, member of the European Parliament. The 'Thomas Celebration' tries to reach doubting people like Thomas with the Gospel and came originally from Finland (about 1990). Raad van Kerken in Nederland, accessed 31.01.12019, https://www.raadvankerken.nl/pagina/339/bomvolle _kerken\&highlight=thomasvier. 


\section{0-2018: REDISCOVERY OF HOLY COMMUNION NEEDED}

In 2010 there was a new big change in my life. I reached the age of 65 and became a pastor emeritus. It was a great surprise that after two years I was called as an interim-minister to a parish where the young local minister had caused problems - at least in the eyes of the church council-and was set apart, but not yet fired. The church council did not know how to handle it. They needed an experienced minister for a while, and I accepted the challenge. It was a difficult situation, but I was glad I could help. I gave them my own printed copy of the rules governing church life. This was the first thing I did, and it was really necessary. I worked there for two and a half years. It was a good time, but after a while I realised this parish had little understanding of the sacramental life of the church. There were no Baptisms during that period and the celebration of Holy Communion seemed to be problematical. People avoided coming to church if Holy Communion was celebrated, for several reasons. One of the reasons - in my view-was secularism and loss of biblical knowledge. Even members of the church council stayed away. In my sermons I tried to explain the holiness of the Lord's Supper, or Holy Communion, but explanation alone was not enough. We talked it over in gatherings, several times, and I was really shocked and fell silent, as I heard that two of the office bearers simply proposed a radical solution, namely to abolish the Lord's Supper completely. In the next gathering we talked it over of course and it was clear that a rediscovery of the meaning of Holy Communion was needed. Then I realised that there was a lot of work to do for the Holy Spirit and me.

\section{6-2018: SOME DEVELOPMENTS IN THE NETHERLANDS}

After having shared my own experiences with secularism as a local pastor I will sketch briefly some broader developments in our country. Secularism is a reality, especially in the Netherlands. It is often said that the Netherlands is one of the most secularised countries of Western Europe. There are scientific sociological approaches, trying to explain secularism with figures, schedules and graphics of the ongoing loss of churchgoers, as if secularism is completely scientific or measurable in such a way. Already in 1967 the first sociological investigation on religion, faith, and non church- 
going attitudes of the Dutch population was published in our country. ${ }^{25}$ This investigation was done by Attwood Statistics and used the method of survey, direct interview or inquiry, a technique normally used in market research. It was supported by an existing well known Dutch Women's Weekly Magazine, with the same name as my own: Margriet. This was the beginning of a long lasting tradition of investigations, starting in 1966, and then renewed every ten years. The results of the first investigation were amazing for that time. It was now written down in black and white, that only less than half of the Dutch population believed in a personal God and about $40 \%$ did not believe in life after death. The report worked as if an alarm bell was ringing, and at the same time it was strongly criticized. Was this investigation worth-while? Was the right methodology used? After this first investigation five others followed, and the latest one appeared in $2016 .{ }^{26} \mathrm{It}$ shows the continuation of secularism and secularisation. Signs of it are the shrinking Christian communities, with church buildings becoming superfluous, and many of our ministers are working part-time or leaving, because the money to pay them is no longer there. Besides that, we are confronted with a growing lack of biblical knowledge. The positive news is that young people are going to church, not only because it is expected of them, or because they are used to it. They go to church because they want to, convinced as they are. The youngest report says that nowadays $11,7 \%$ of the Dutch population is Roman-Catholic, $8,6 \%$ belongs to the PCN, 4,2\% belongs to the smaller Protestant churches, with very severe strict orthodox reformed 'zwartekousenkerken,' evangelical churches, Baptist churches, Salvation Army etc. And we have a lot of migrant churches in the Netherlands (about one million members). ${ }^{27}$ It seems that no less than $68 \%$ of the Dutch population is churchless nowadays. It would be no surprise if a further decline in numbers of churchgoers will follow in the near future, from $25 \%$ now to less than $20 \%$ in the next decade. Does it mean that those who are not churchgoers are also non believers or purely rationalists? ${ }^{28}$ No, there are certainly believers, but they

\footnotetext{
${ }^{25}$ George Herman Laurens ZeEgers, G. Dekker, and J.W.M. Peters, God in Nederland. Statistisch onderzoek naar godsdienst en kerkelijkheid ingesteld in opdracht van de geïllustreerde pers NV (Amsterdam: Van Ditmar, 1967).

${ }^{26}$ Ton Bernts, Joantine Berghuijs, Joris Kregting, Christian van der Heijden, Joep de HART, God in Nederland (Baarn: Ten Have, 2016).

${ }^{27}$ Irene M. PluiM and Elza KUYK, Relaties met Migrantenkerken (Utrecht: Kerkinactie (SoWKerken), 2002).

${ }^{28}$ H.W. de KNIJFF, Tegenwoordigheid van geest als Europese uitdaging: Over secularisatie, wetenschap en christelijk geloof (Zoetermeer: Boekencentrum, 2013).
} 
may not necessarily belong to any church. ${ }^{29}$ There are other religions, of course - including Judaism, Islam and Buddhism. Today we have a Muslim minority of about $5 \%$, with Jews and Buddhists make up $6 \%$ of the population. The famous Dutch poet Jan Hendrik Leopold once made a little poem, as if the whole of mankind was divided in two kinds of people: the intelligent-notpious ones and the pious-not-intelligent ones.

Christenen, Joden, Parsen, Moslemin, zij dolen allen; voor wie toe wil zien, vervalt de gansche menschheid slechts [in tweeën, twee soorten enkel worden er ontdekt: intelligente menschen zonder vroomheid en vrome menschen zonder intellect.
Christians, Jews, Persians, Moslemin, They all stray around; and we have seen, the whole of mankind in two parts divided, just two of them can be really discovered: intelligent people, but not pious hence and pious people without intelligence. ${ }^{30}$

Apart from those who belong to one of the religious institutions, we have others. They are not really a group. I mean those who still believe, there must be 'something' (in our Dutch language 'iets'). They are seeking souls, trying to find a meaningful life. They suppose there must be 'more' between heaven and earth, but they do not accept the traditional religious convictions. Therefore we call them 'ietsisten' ${ }^{31}$ It is clear that traditional churches have lost influence and power. Traditional churches are mostly filled now with old and grey people over fifty or even sixty and, unfortunately, our churches have little attraction for young people. The good news however is that there is another movement within our PCN trying to find new ways of being church in our secular, liberal and plural time.

${ }^{29}$ H.J. Schulz, "Christendom incognito; notities over de toekomst van de kerk," in Gert Oтто (ed.), Hedendaags geloof (Hilversum, Antwerpen: Paul Brand, 1966), 182-192; Trutz RENDTORFF, Christendom buiten de kerk (Baarn: Bosch en Keuning, 1973). Original German edition: Christentum außerhalb der Kirche (Hamburg: Furche Verlag, 1969); Ronald PINO, Bevrijding. Theologie voor chronisch buitenkerkelijken (Haarlem: Altamira-Becht, 2005).

${ }^{30}$ Georg Puchinger, "Interview met Prof. Dr. G.Th. Rothuizen," in Georg PuChinger, Christen en Secularisatie (Delft: Meinema, 1968), 307-328, 327 (translation of the poem by Margriet Gosker, 2019).

${ }^{31}$ Taede SMEDES, God, Iets of Niets?De postseculiere maatschappij tussen 'geloof' en 'ongeloof' (Amsterdam: Amsterdam University Press, 2016²). 


\section{THE PASSION, PIONEER PLACES, AND A NEW FORM \\ OF EPISKOPÈ}

There are some new initiatives to bring the Gospel to the wider community, like the Passion. ${ }^{32}$ The Passion tells the story of Jesus' death and resurrection during a music on the streets of a Dutch city. In 2019, it will be the $9^{\text {th }}$ staging in Dordrecht. Well known artists (not especially Christians) sing the story of Jesus and a procession with thousands of people follow behind a large white lightning illuminated cross, which is carried through the streets of a chosen city. It is all broadcasted by Dutch TV and also by the British BBC.

Another initiative is that of the pioneer places. One or more pioneers try to build up new small Christian communities, starting with nothing than their own hands, their own belief and the help of the Holy Spirit, mostly in a city or suburb. They usually function apart from established churches without regular ministries, but they are morally and financially supported by the PCN. In the last decade more than a hundred of these pioneer places came into existence in the Netherlands, unfortunately not supported ecumenically. Pioneer places especially for young families are called 'kliederkerken' (messy churches). ${ }^{33}$ There are also pioneer places where a kind of a monastic life is practised. ${ }^{34}$ All these new developments (mostly Protestant) change the spiritual landscape and, hopefully, will bring the Gospel to new generations. After ten years of pioneering it is time to evaluate these developments, and that is precisely what the PCN is now doing.

Another new development is the creation recently of eleven 'classispredikanten' (in 2018) having the task of episkopè. We never have had Protestant bishops in the Netherlands. I myself and some others expressed a wish some twenty years ago - thanks to the WCC Lima-discussions - for an episcopal element in our church government. ${ }^{35}$ It was apparently necessary now for the PCN to create a new, lighter, but more top-down structure of church government. There was a proposal indeed to call them

\footnotetext{
32 "Veelgestelde vragen," The Passion, accessed 27.01.2019, https://www.thepassion.nl/veelge stelde-vragen/.

33 "What Messy Church is and isn't," Messy Church, accessed 28.01.2019, https://www.messy church.org.uk/what-messy-church-and-isnt.

${ }^{34}$ Nijkleaster, accessed 27.01.2019, https://nijkleaster.frl/.

${ }^{35}$ Margriet GoskeR, Het ambt in de oecumenische discussie. De betekenis van de LimaAmbtstekst voor de voortgang van de oecumene en de doorwerking in de Nederlandse SoW-Kerken (Delft: Eburon, 2000).
} 
bishops, but this was refused, because the PCN has a strong non-hierarchical tradition with an anti-papist suspicion. ${ }^{36}$

\section{OPEN QUESTIONS}

In 2018, a Study of the Protestant Church in the Netherlands was published, dealing with the question of what should be changed to make the PCN fit for the future. ${ }^{37}$ I was involved in the production of this Study Document, knowing that we cannot continue in the way we always have done. In my view, many important ecumenical questions are now at stake. Is it obvious that we must always have the threefold ministry, or even the ministry itself? What is the importance of an academic education for ministers? ? $^{38}$ Are the ordained ministers the only ones allowed to administer the sacraments or can everybody do it, even without ordination? ${ }^{39}$ In fact this is already the case. What exactly is the importance of the ordination $?^{40}$ Do we need official membership always, or can we welcome just everybody without church membership? How many members are required to bring a pioneer place into existence? What precisely is the relationship between pioneer places and the PCN? And what is the relationship between migration churches and the PCN? Do these pioneer places have to obey the church order of the PCN, or are exceptions possible? What does it all mean for our ecumenical relationships? ${ }^{41}$ These questions arise and are waiting for answers. They are very important for the ecumenical movement as a whole.

\footnotetext{
${ }^{36}$ Margriet GOSKER, "Waarom reageren Nederlandse protestanten vaak zo allergisch op de bisschop?," in B. Jan AALBERS and Peter Nissen (eds.), De bisschop, kerkscheidend of kerkverenigend? Bijdragen over het bisschopsambt in de oecumene. Ter nagedachtenis van ds. Nico van den Akker (Delft: Eburon, 2002), 93-101.

${ }^{37}$ René de ReUVER and Martijn VelLEKOOP. Mozaïek van Kerkplekken. Over verbinding tussen bestaande en nieuwe vormen van kerk-zijn. Synodaal rapport van de Protestantse Kerk in Nederland, versie 21 december 2018, 25.

${ }^{38}$ Margriet GoSKER, "Gaat de academisch gevormde predikant straks verdwijnen?," Confessioneel 130 (2018), 18: 8-9.

${ }^{39}$ Hans Kronenburg and Margriet Gosker, "Een wissel gemist?," Kerk en Theologie 60 (2009), 2: 143-159.

${ }^{40}$ Margriet Gosker, "De vreugde van het ambt," Confessioneel 130 (2018), 18: 10.

${ }^{41}$ Especially the Lima-Document (1982) is mentioned in Mozaïek van Kerkplekken, 45. Baptism, Eucharist and Ministry, WCC Faith and Order Paper 111 (Geneva: WCC Publications, 1982, $1986^{19}$ ). Same in Dutch: Doop, Eucharistie en Ambt. Verklaringen van de commissie voor Geloof en Kerkorde van de Wereldraad van Kerken (Amersfoort: Archief van de Kerken, $1983^{2}$ ); in German: Taufe, Eucharistie und Amt. Konvergenzerklärungen der Kommission für Glauben und
} 


\section{BIBLIOGRAPHY}

ADOLFS, Robert. Het graf van God: heeft de kerk nog toekomst? Utrecht: Ambo, 1966.

Bernts, Ton, Joantine Berghuijs, Joris Kregting, Christian van der Heijden, and Joep de HART, God in Nederland. Baarn: Ten Have, 2016.

Best, Thomas F., and Günther Gassmann. On the way to fuller Koinonia. Faith and Order Paper 166. Geneva: WCC Publications, 1994.

Boon, Rudolf. Het Christendom op de tocht. Een onderzoek naar de opkomst van het WestEuropese atheisme. Kampen: Kok, 1976.

Cliteur, Paul B. "Op zoek naar het bezielend verband.” Justitiële verkenningen 20 (1994) 6: 9-36.

DeKKeR, Wim. Afwezigheid van God. Een onderzoek naar antwoorden bij W. Pannenberg, K.H. Miskotte en A. Houtepen. Zoetermeer: Boekencentrum, 2011.

Delumeau, Jean. Einde van het Christendom? Hilversum: Gooi en Sticht, 1978.

DIJK, Janet van (ed.). God is niet dood: Over religie als thema van de 21 ste eeuw. Toer van de Protestantse Kerk in Nederland. Zoetermeer: Boekencentrum, 2007.

ENDEDIJK, Henk C. Aan deze plaats doet Gij Uw woorden horen. De Geschiedenis van de Stichting Steun Kerkbouw, 1954-1994. Leusden: Stichting Steun Kerkbouw, 1994.

Gosker, Margriet. Het ambt in de oecumenische discussie. De betekenis van de Lima-Ambtstekst voor de voortgang van de oecumene en de doorwerking in de Nederlandse SoW-Kerken. Delft: Eburon, 2000.

Gosker, Margriet. "Waarom reageren Nederlandse protestanten vaak zo allergisch op de bisschop?" In B. Jan AALBERS and Peter Nissen (eds.), De bisschop, kerkscheidend of kerkverenigend? Bijdragen over het bisschopsambt in de oecumene. Ter nagedachtenis van ds. Nico van den Akker, 93-101. Delft: Eburon, 2002.

GosKer, Margriet. "Gaat de academisch gevormde predikant straks verdwijnen?" Confessioneel 130 (2018) 18: 8-9.

Gosker, Margriet. "De vreugde van het ambt." Confessioneel 130 (2018) 18: 10.

Hellemans, Staf. Het tijdperk van de wereldreligies. Religie in agrarische civilisaties en in moderne samenlevingen. Zoetermeer: Meinema, 2007.

Hart, Joep de, and Pepijn VAN Houwelingen. Christenen in Nederland. Kerkelijke deelname en christelijke gelovigheid. Den Haag: Sociaal en Cultureel Planbureau, 2018.

Hermans, Chris (ed.). Is er nog godsdienst in 2050? Budel: Damon, 2003.

HolyOAKE, George Jacob. "Principles of Secularism.” Project Gutenberg. Accesed 03.01.2019. https://www.gutenberg.org/files/36797/36797-h/36797-h.htm.

JACOBS, J.G. Geloven na de dood van God. Reeks Witte Beertjes 1089. Utrecht, Antwerpen: A.W. Bruna \& Zoon, 1967.

JONKER, Jan. Gaan uw kinderen nog naar de kerk? Kampen: Kok, 1982.

Jonkers, Jan, and Jan te Winkel. Adieu. Mensen keren de kerk de rug toe, Jongbloed, Leeuwarden, [1980].

KAMP, Klaas van der, and Beppie VAN LAAR, Raven. Over eenheid als waardering voor God. Amersfoort: Raad van Kerken in Nederland, 2014.

KNIJFF, H.W. de. Tegenwoordigheid van geest als Europese uitdaging. Over secularisatie, wetenschap en christelijk geloof. Zoetermeer: Boekencentrum, 2013.

Kirchenverfassung des Ökumenischen Rates der Kirchen (Frankfurt am Main, Paderborn: Verlag Otto Lembeck, Verlag Bonifatius-Druckerei, $1982^{2}$ ); in French: Baptême, Eucharistie, Ministère. Convergence de la foi (Paris: Le Centurion, 1982). 
Kronenburg, Hans, and Margriet GosKer. "Een wissel gemist?" Kerk en Theologie 60 (2009) 2: $143-159$

KÜNG, Hans, Bestaat God? Antwoord op de vraag naar God in deze tijd. Hilversum: Gooi en Sticht, 1978 (Existiert Gott? Antwort auf die Gottesfrage der Neuzeit. München, Zürich: R. Piper \& Co. Verlag, 1978).

McAfEe Brown, Robert. Het geloof, een afgedane zaak? Baarn: Bosch en Keuning, 1977 (Original edition: Is Faith Obsolete? Philadelphia: The Westminster Press, 1976).

MANensChiJn, Gerrit. God is zo groot dat Hij niet hoeft te bestaan. Baarn: Ten Have, $2002^{2}$.

Melidoro, Domenico, Principles of Secularism. Is the Clash among Principles Necessary? ResearchGate. Accessed 03.01.2019. https://www.researchgate.net/publication/264120006 _The_Principles_of_Secularism_Is_the_Clash_among_Values_Necessary.

Meuleman, Guus. 'Het begrip secularisatie.' In Gerard DeKker, K. Ulrich GäBler. Secularisatie in theologisch perspectief. Kampen: Kok, z.j. [1988], 16-30.

NiETzSCHE, Friedrich. Die fröhliche Wissenschaft. Chemnitz: Verlag von Ernst Schmelzner 1882.

PAUL, Herman. Secularisatie. Een kleine geschiedenis van een groot verhaal. Amsterdam: Amsterdam University Press, 2017.

PAul, Herman. De slag om het hart. Over secularisatie van verlangen. Utrecht: Boekencentrum, 2017.

PINO, Ronald. Bevrijding. Theologie voor chronisch buitenkerkelijken. Haarlem: Altamira-Becht, 2005.

Plaisier, Arjan, and Leo J. Koffeman (eds.). The Protestant Church in the Netherlands: Church Unity in the $21^{\text {st }}$ Century. Wien, Zürich, Berlin: LIT Verlag, 2014.

PLUIM, Irene M., and Elza KUYK. Relaties met Migrantenkerken. Utrecht: Kerkinactie (SoWKerken), 2002

Prosman, A.A.A. Geloven na Nietzsche. Zoetermeer: Boekencentrum, 2007.

Puchinger, George. "Interview met Prof. Dr. G.Th. Rothuizen.” In George Puchinger. Christen en Secularisatie, 307-328. Delft: Meinema, 1968.

Puchinger, George. "Interview met Prof. Dr. H van Oyen." In George PuChinger. Christen en Secularisatie, 181-201. Delft: Meinema, 1968.

RendTORFF, Trutz. Christendom buiten de kerk. Baarn: Bosch en Keuning, 1973 (original edition: Christentum außerhalb der Kirche. Hamburg: Furche Verlag, 1969.

Reuver, René de, and Martijn VelleKoOP. Mozaïek van Kerkplekken. Over verbinding tussen bestaande en nieuwe vormen van kerk-zijn. Synodaal rapport van de Protestantse Kerk in Nederland, versie 21 december 2018.

RogIER, L.J. "Rede gehouden voor het Congres van de Organisatie van Reünisten der Societas Studiosorum Reformatorum te Lunteren op 29 september 1967." In George PUCHINGER. Christen en Secularisatie, 9-33. Delft: Meinema, 1968.

SCHIFFERS, Norbert. "Analyses bij Nietzsches 'God is dood'." Concilium 17 (1981), 5: 72-84.

SChUlz, H.J. "Christendom incognito; notities over de toekomst van de kerk." in Gert Отто (ed.). Hedendaags geloof, 182-192. Hilversum, Antwerpen: Paul Brand, 1966.

Smedes, Taede A. God, Iets of Niets? De postseculiere maatschappij tussen 'geloof' en 'ongeloof'. Amsterdam: Amsterdam University Press, $2016^{2}$.

TIELEMAN, Dick. Sekularisatie - zure regen of zegen voor geloof en kerk? Kampen: Kok, 1989.

VROOM, Henk M. "Wie kan nog een Christen genoemd worden?" In J.M. VliJM (ed.). Buitensporig geloven. Studies over randkerkelijkheid. Kampen: Kok, 1983.

VRoom, Henk M. Plaatsbepaling. Christelijk geloof in een seculiere en plurale cultuur. Zoetermeer: Meinema, 2006.

Wyneken, Gustav. Afscheid van het Christendom. Amsterdam: Moussault, 1966 (Abschied vom Christentum. München: Szczesny Verlag, 1963). 
ZAhrnt, Heinz. Gott kann nicht sterben. München: R. Piper \& Co. Verlag, 1970.

ZeEgers, George Herman Laurens, G. Dekker, J.W.M. Peters. God in Nederland. Statistisch onderzoek naar godsdienst en kerkelijkheid ingesteld in opdracht van de geïllustreerde pers NV. Amsterdam: Van Ditmar, 1967.

\title{
NO I CO? \\ DOŚWIADCZENIA SEKULARYZMU W HOLANDII I MOJA DROGA W ZMIERZANIU SIĘ Z NIM JAKO LOKALNEJ PASTORKI
}

\author{
Streszczenie
}

Artykuł składa się z trzech części. We wprowadzeniu Autorka stwierdza, że istnieje wiele teorii i idei sekularyzmu, podaje również krótkie objaśnienia tego fenomenu zarówno pozytywne, jak i negatywne. Sekularyzm w Polsce jest odmienny od sekularyzmu w Holandii, która jest jednym z najbardziej zsekularyzowanych krajów Zachodniej Europy. W drugiej części Autorka ukazuje jak — jako lokalny pastor — doświadczała sekularyzmu w ostatnich pięciu dekadach: indyferentyzm, spadek zaangażowania i wiedzy biblijnej, spadek liczby ordynowanych, utrata poczucia życia sakramentalnego w Kościele, zamykanie Kościołów, zamykanie fakultetów teologicznych itd. $Z$ drugiej strony pozytywna strona sekularyzmu objawiła się nie tylko w większej autentyczności i elastyczności w Kościele, ale również w zniesieniu niewolnictwa, większej wolności dla kobiet i dzieci oraz dla mniejszości. W trzeciej części Autorka pokazuje, jak staramy się odpowiedzieć na nowe wyzwania. W zakończeniu stawia kilka otwartych pytań, na które odpowiedzi są bardzo ważne dla całego ruchu ekumenicznego.

Słowa kluczowe: ekumenizm; sekularyzm; koniec chrześcijaństwa; wiara; zaangażowanie; ordynacja; episkopè; Męka; pionierskie punkty; Holandia. 